УДК 378:364-68

Т. С. Острянко, к. пед. н., доцент, Л. Ф. Лєскова, ст. викладач

\title{
ПЕДАГОГІЧНА МАЙСТЕРНІСТЬ ВИКЛАДАЧА СОЦІАЛЬНОЇ РОБОТИ - ЗАПОРУКА УСПІШНОГО ПРОФЕСІЙНОГО СТАНОВЛЕННЯ МАЙБУТНІХ СОЦІАЛЬНИХ ПРАЦІВНИКІВ
}

Актуальність теми дослідження. Проблема педагогічної майстерності викладача соціальної роботи на сьогоднішній день набуває особливого значення, що обумовлене як викликами сучасного суспільства так і новим розумінням змісту соціальної роботи.

Постановка проблеми. Підготовка висококваліфрікованого та конкурентоспроможного фрахівия соціальної сфери в сучасних умовах розвитку українського суспільства вимагає відповідного рівня педагогічної майстерності викладача соціальної роботи.

Аналіз останніх досліджень і публікацій. Питання сутності і змісту педагогічної майстерності досліджували вітчизняні й зарубіжні науковці - А. І. Кузьминський, І. А. Зязюн, Н. В. Кузьміна, Н. В. Кухарєв. Підходи щодо визначення змісту і сутності поняття педагогічної майстерності проаналізовано В. В. Ягуповим.

Виділення недосліджених частин загальної проблеми. Малодослідженими залишаються теоретичні та практичні аспекти проблеми розвитку педагогічної майстерності викладача соціальної роботи у вищих навчальних закладах.

Постановка завдання полягає у визначення головних складників майстерності викладача соціальної роботи та шляхів ії підвищення у процесі підготовки майбутніх соціальних працівників.

Виклад основного матеріалу. Педагогічна майстерність викладача соціальної роботи вищого навчального закладу є інтегрованою якістю особистості, що забезпечує стабільну результативну діяльність викладача, його профресійно-педагогічний саморозвиток, самоактуалізацію на основі гуманізму, психолого-педагогічної, методичної та фрахової компетентності, особистісних характеристик та профресійної мобільності.

Висновки. Ефрективним шляхом підвищення педагогічної майстерності викладачів соціальної роботи є підвищення кваліфрікації в інших навчальних закладах та стажування, зокрема у закордонних ВНЗ, що збагачують індивідуальний досвід людини, надають можливість ознайомитися і практикувати різні моделі створення і поширення знань.

Ключові слова: педагогічна майстерність; викладач соціальної роботи; підготовка майбутніх соціальних працівників.

T. S. Ostrianko, Candidate of Pedagogical Sciences, Associate Professor,

L. F. Leskova, Senior Lecturer

\section{SOCIAL WORK TEACHERS' PEDAGOGICAL SKILLS - THE KEY TO SUCCESSFUL PROFESSIONAL FORMATION OF FUTURE SOCIAL WORKERS}

Urgency of the research. The problem of the social work teacher's pedagogical skill is of particular importance to date, both due to the challenges of modern society and a new understanding of the content of social work.

Target setting. To prepare highly qualified and competitive specialist of social sphere in modern conditions of development of Ukrainian society demands an appropriate level of social work teacher's pedagogical skill.

Actual scientific researches and issues analysis. The questions of essence and content of pedagogical skills are researched by domestic and foreign scientists: O. J. Kuzminski, I. A., Sasun, N. V. Kuzmina, N. V. Kukharev. Approaches to the definition of the content and concept of teaching skills analyzed Vladimir Agupova.

Uninvestigated parts of general matters defining. Theoretical and practical aspects of the problem of development of social work teacher's pedagogical skill in higher education remain unexplored. 
The research objective is to determine the main components of social work teacher's skill and ways of its improvement in the process of training of future social workers.

The statement of basic materials. Social work teacher's pedagogical skill in higher educational institutions is integrated personality feature, which ensures stable performance of the teacher, their professional-pedagogical self-development, self-actualization on the basis of humanism, psychopedagogical, methodological and professional competence, personal characteristics, appropriate image and professional mobility.

Conclusions. Effective way to improve social work teacher's pedagogical skill is training in other educational institutions and internship, including in foreign universities that enrich individual human experience, give the opportunity to learn and practice various models of creating and disseminating knowledge.

Keywords: teaching skills; social work teacher; training of future social workers.

DOI: 10.25140/2412-1185-2018-2(12)-74-80

Актуальність теми дослідження. Загострення ряду глобальних проблем життєдіяльності людини, створення масштабної державної системи соціального захисту населення обумовлює значимість соціальної роботи як однієї із найважливіших гуманітарних професій, що є необхідними для стійкого розвитку та соціальної безпеки суспільства. I як наслідок цього, до сучасного фахівця із соціальної роботи ставляться нові вимоги: високий інтелектуальний потенціал, здатність до постійного навчання та інновацій, креативної взаємодії, саморозвитку, здатність мислити стратегічно, приймати нестандартні рішення, мати стійкий світогляд.

У сучасних умовах розвитку професійної освіти в Україні особливого значення набуває проблема підвищення професіоналізму, і зокрема майстерності педагогічних кадрів. В наш час педагогічна майстерність полягає насамперед в умінні швидко і якісно, найбільш оптимальним шляхом вирішувати освітні завдання в конкретних умовах.

Постановка проблеми. Сьогодення розвитку нашої держави потребує підготовки соціальних працівників, психологів, менеджерів організацій, соціологів, управлінців, які найближчим часом мають заповнити професійну нішу відповідно до вимог оновленого суспільства.

Модернізація української освітньої системи на сучасному етапі потребує переосмислення та залучення національного й зарубіжного досвіду в процесі організації освіти та навчання, а також упровадження у практику інновацій. Конкурентоспроможність національної системи освіти у європейському і світовому просторі має забезпечуватись високою якістю підготовки випускників вищих навчальних закладів, які готують висококваліфікованих фахівців для соціальної сфери. Успішне вирішення цього завдання значною мірою залежить від викладачів, зокрема викладачів соціальної роботи, їхнього науково-творчого потенціалу, рівня культури, професіоналізму та, не менш важливої складової, високої педагогічної майстерності. Педагогічна майстерність викладача соціальної роботи є цілісним поєднанням наукових закономірностей та інноваційного педагогічного досвіду. Тому розвиток педагогічної майстерності викладача соціальної роботи передбачає доведення педагогічної майстерності до вищого рівня, від чого залежить якість підготовки майбутніх фахівців із соціальної роботи з вищою освітою.

Аналіз останніх досліджень і публікацій. Теоретичні аспекти феномена педагогічної майстерності викладача вищої школи, сутність та складові елементи цього поняття залишаються малодослідженими. У педагогічній літературі це поняття найбільш повно розкрите стосовно шкільного вчителя й викладача педагогічного ВНЗ, проте відмічається відсутність єдиного розуміння цього терміну. Проблему визначення сутності і змісту педагогічної майстерності досліджували вітчизняні й зарубіжні науковці, серед яких: А. І. Кузьминський, І. А. Зязюн, Н. В. Кузьміна, Н. В. Кухарєв, С. С. Вітвицька. Детальний аналіз підходів до визначення змісту і сутності поняття педагогічної майстерності здійснив В. В. Ягупов. У наукових доробках таких дослідників як О. Е Коваленко, В. М. Гринькова, Н.П.Корогод, В. А. Семиченко висвітлені питання, пов'язані із підготовкою науково-педагогічних працівників, підвищенням їхньої кваліфікації та педагогічної майстерності в системі вищої професійної освіти.

Виділення недосліджених раніше частин загальної проблеми. Незважаючи на значний інтерес науковців і педагогів-практиків до педагогічної майстерності, проблема розвитку педаго- 
гічної майстерності викладача соціальної роботи у вищих навчальних закладах є майже не дослідженою як у теоретичному, так і практичному аспектах. Водночас, донині не існує єдиного підходу щодо визначення сутності, основних складників педагогічної майстерності та психологопедагогічних умов її розвитку, зокрема у викладачів соціальної роботи.

Постановка завдання. Метою публікації $\epsilon-$ означити сутність поняття «педагогічна майстерність», виділити головні складники майстерності викладача соціальної роботи та шляхи її підвищення в процесі підготовки майбутніх соціальних працівників.

Виклад основного матеріалу. На сучасному етапі модернізації системи освіти й виховання в Україні особливої гостроти й актуальності набувають питання підвищення педагогічної майстерності викладачів як загальноосвітніх шкіл, так і вищих навчальних закладів. Як зазначено в Національній доктрині розвитку освіти України у XXI столітті, підготовка педагогічних працівників $\epsilon$ центральним завданням модернізації освіти, провідним принципом державної освітньої політики. Держава забезпечує умови для підвищення престижу і соціального статусу педагогічних та науково-педагогічних працівників, їхнього профресійного і культурного зростання.

Підготовка кадрів для соціальної сфери у вищих навчальних закладах України, зокрема, і соціальних працівників, бере свій початок з 90-х років XX ст.., разом із появою в 1991 році у Кваліфікаційному довіднику нових посад: «соціальний працівник» та «спеціаліст із соціальної роботи». Серед спеціальних (фахових) компетентностей майбутніх соціальних працівників виділяють здатності до аналізу та оцінки соціально-політичних процесів; психічних властивостей, станів і процесів; процесів становлення, розвитку та соціалізації особистості, розвитку соціальної групи і громади; проблем, потреб, специфічних особливостей та ресурсів клієнтів тощо. Тобто майбутній фахівець із соціальної роботи має володіти знаннями із психології, соціології, політології, медицини, менеджменту, юриспруденції та інших дисциплін, що визначає мультидисциплінарність даної професії. Через це професійна підготовка соціальних працівників також має здійснюватись комплексно [9, с. 129]. Оскільки система професійної підготовки соціальних працівників не може існувати без науково-педагогічних працівників (викладацького складу), рівень їх компетентності та професіоналізму є дуже важливою особливістю системи вищої освіти.

Профресія педагога висуває до його особистості низку специфрічних вимог. Адже педагог повинен вчити здобувати знання, володіти сукупністю професійно-педагогічних умінь та здатністю впливати на формування особистості студента, створювати йому умови для розвитку та саморозвитку. Ще П. П. Блонський писав: «Ми не збираємось навчити студента «всьому», але ми повинні навчити його самостійно, протягом усього майбутнього життя, коли поряд не буде ні лекторів, ні викладачів, вивчити все, що йому потрібно» [7, с. 33].

Найвищим рівнем педагогічної діяльності, що проявляється у постійному удосконаленні мистецтва навчання, виховання та розвитку людини, є педагогічна майстерність. Педагогічна майстерність викладача вищої школи виражається у його професійній діяльності і окремо від особистості не існує. На сьогодні, у педагогіці немає єдиного погляду на сутність професійної майстерності викладача. Так, деякі науковці майстерність пов'язують із оволодінням методами, прийомами виховання, інші - із особистістю викладача, його індивідуальністю.

Існують різні підходи до визначення сутності і змісту поняття педагогічної майстерності. Так, Н. В. Кузьміна і Н. В. Кухарєв розуміють під нею «найвищий рівень педагогічної діяльності...., що проявляється у тому, що за відведений час педагог досягає оптимальних результатів» $[6$, c. 28]. Одним із перших системне уявлення про педагогічну майстерність як обов'язковий елемент професійної компетенції учителів і як самостійну навчальну дисципліну у педагогічному ВН3 сорормулював та ввів у практику підготовки спеціалістів І. А. Зязюн [ 4, с. 54]. Більшість його ідей можуть бути пристосовані і до усвідомлення сутності майстерності викладача вищої школи, оскільки передбачають наявність професійного підходу та уміння ефективно вирішувати найрізноманітніші педагогічні задачі.

Автори підручника «Педагогічна майстерність» за редакцією І. А. Зязюна розуміють зміст терміну «педагогічна майстерність» - «найвищий рівень педагогічної діяльності (якщо характеризуються якісні показники результату), як прояв творчої активності особистості педагога (якщо характеризується психологічний механізм успішної діяльності) «...Педагогічна майстерність - це комплекс властивостей особистості, який забезпечує високий рівень самоорганізації професійної діяльності на рефлексивній основі» [ 8, с. 30]. 
На думку В. Г. Кременя, найважливішою функцією викладача є його уміння сприяти студентам у ефективному і творчому засвоєнні знань, критично переосмислювати та оцінювати отриману інформацію. Не випадково у світовому освітньому середовищі з'явився спеціальний термін facilitator - допомога, сприяючий, допомагаючий навчатися. Автор підкреслює, що «навіть якщо використовувати найсучасніші комп'ютерні системи, високі комунікаційні технології які, поза сумнівом, стимулюють динаміку і ефективність навчального процесу, підвищують інтерактивність освітнього середовища, ніхто і ніщо не зможе повністю витіснити і замінити мистецтво безпосереднього педагогічного діалогу «учитель-учень». Тому особливо важливою є підготовка високопрофесійних педагогічних і науково-педагогічних працівників, котрі мають відповідати інтеграційному критерію «педагогічна майстерність = мистецтво комунікації + новітні технології» [5, с. 15].

Педагогічна майстерність викладача соціальної роботи складається 3 таких компонентів: професійні цінності та ставлення, педагогічні здібності, професійно необхідні знання, професійно необхідні уміння та навички, педагогічна техніка, педагогічно-економічна культура., зовнішня культура [2, с. 13].

Викладач вищого навчального закладу взагалі, і викладач соціальної роботи зокрема, повинен постійно працювати над удосконаленням своєї педагогічної майстерності, від чого значною мірою залежать результати його роботи.

Педагогічна майстерність викладача соціальної роботи - сукупність якостей особистості, які забезпечують високий рівень самоорганізації професійної діяльності педагога. Професійні знання $є$ фундаментальною основою педагогічної майстерності і охоплюють три блоки навчальних дисциплін: психолого-педагогічні, фрахові, соціально-гуманітарні.

Педагогічна техніка передбачає наявність трьох груп умінь:

- здійснювати навчально-виховний процес, виховну роботу;

- взаємодіяти зі студентами, управляти ними в процесі різноманітної діяльності;

- управляти собою, своїм емоційним станом, мовленням, тілом, що виявляється у поведінці. Педагогічні вміння допомагають формуванню професійної позиції викладача, дають змогу отримати результат, адекватний цілям, задумам.

До педагогічних здібностей належать комунікативність, креативність (творчість), рефрлексія (аналіз власного психічного стану); перцептивні (здібності до сприйняття нового), інтелектуальні, організаторські.

Педагогічна моральність передбачає гуманістичну спрямованість особистості викладача і охоплює його ціннісні орієнтації, ідеали, інтереси. Втілюється вона в педагогічній позиції викладача, у виборі конкретних завдань навчально-виховного процесу, впливає на взаємини зі студентами, визначає гуманістичну стратегію педагогічної діяльності.

До професійно значущих якостей зараховують доброзичливість, об'єктивність, вимогливість, самостійність, самоконтроль, порядність, оптимізм, наявність педагогічних здібностей. Ці якості підвищують продуктивність та ефективність педагогічної діяльності.

Зовнішню культуру викладача формують одяг, зачіска, макіяж, постава, мовлення, форми невербального спілкування тощо.

Усі ці компоненти-характеристики створюють передумови для перетворення педагогічної діяльності на мистецтво. Досягнення цього є тривалим і складним процесом. У цьому процесі виокремлюють кілька етапів (Р. Піонова).

1. Профресіоналізм. Ним володіє випускник вищого педагогічного закладу. У процесі самостійної роботи в навчальному закладі триває його професійне зростання, вдосконалення, але інтенсивніше й цілеспрямованіше. Ефективність цього процесу залежить від установки на самоосвіту і самовиховання, від наявності відповідної програми. Крім того, викладач може вчитися в педагогів-майстрів, аналізувати роботу досвідчених колег, відвідувати семінари, курси, брати участь у наукових і практичних конференціях.

2. Педагогічна майстерність. У процесі діяльності психолого- педагогічна культура викладача зростає. Окрім репродуктивної діяльності, він займається педагогічним моделюванням, пошуком нових елементів у навчально-виховному процесі, його вдосконаленням. Одночасно розвиваються педагогічні здібності, якості, збагачується методичний арсенал. Однак розвиток структурних компонентів педагогічної майстерності відбувається нерівномірно. До педагога-майстра звертаються за порадою та досвідом менш досвідчені колеги. 
3. Педагогічне новаторство. Викладач-новатор вносить принципово нові ідеї у навчальновиховний процес, розробляє нові методичні системи, створює нові педагогічні технології. Внаслідок цього не лише підвищується продуктивність професійної підготовки студентів, а й змінюється їх якість. Стати педагогом-новатором допомагають високий рівень теоретичної і практичної підготовки, інтелектуальні здібності, творчий склад розуму [1, с. 70-75].

Залежно від міри оволодіння педагогічною майстерністю В. Гринькова виокремлює кілька її рівнів:

1) елементарний. У викладача наявні лише окремі якості професійної діяльності, найчастіше це володіння знаннями для виконання педагогічної дії та предметом викладання. Проте через брак спрямованості на розвиток студента, техніки організації діалогу продуктивність його навчально-виховної діяльності є низькою;

2) базовий. Викладач володіє основами педагогічної майстерності (педагогічні дії гуманістично зорієнтовані, взаємини зі студентами і колегами, розвиваються на позитивній основі, добре засвоєно предмет викладання, методично впевнено і самостійно організовано навчально- виховний процес на заняттях). Цього рівня, як правило, досягають наприкінці навчання у ВН3;

3) досконалий. Він характеризується чіткою спрямованістю дій викладача, їх високою якістю, діалогічною взаємодією у спілкуванні. Викладач самостійно планує і організовує свою діяльність на тривалий проміжок часу, головне його завдання - розвиток особистості студента;

4) творчий. Цей рівень характеризується ініціативністю і творчим підходом до організації професійної діяльності. Викладач самостійно конструює оригінальні педагогічно доцільні прийоми взаємодії. Діяльність будує, спираючись на рефлексивний аналіз. У педагога сформовано індивідуальний стиль професійної діяльності [3].

Найважливішими завданнями у процесі підготовки фахівців для соціальної сфери є також корекція направленості навчального процесу. Сьогодні вже є застарілими як традиційний підхід (орієнтований на знання), так і підхід, орієнтований на діяльність. Життя наполегливо вимагає вироблення комплексного підходу, особистісно-, знанієво-, діяльністного його орієнтування. При цьому слід озброїти студента, майбутнього соціального працівника, розумінням необхідності постійної самоосвіти, самовиховання та самовдосконалення протягом усього активного трудового життя, прищепити йому навички й уміння безперервної самоосвіти та прагнення до її здійснення. I, насамкінець, для успішного життя і діяльності у нашому надзвичайно мінливому світі вкрай необхідно формування інноваційного типу мислення, що у свою чергу, потребує від системи освіти інноваційного характеру, оперативної й адекватної відповіді на виклики часу.

Особистісні якості викладача вищого навчального закладу відіграють важливу роль у вихованні і навчанні студентів, оскільки він постійно перебуває у сфері уваги молодих людей. Викладач $є$ для студента як взірцем, так і засобом виховного впливу на нього. Студент, наслідуючи викладача, переймає його знання, вміння, манери тощо. Знання педагога, його кращі моральні й вольові якості $€$ потужним засобом переконання і впливу на студента.

Можна бути професійно компетентним педагогом, тобто вільно орієнтуватися в предметній сорері, системно сприймати і діяти в педагогічній реальності, мати особистісно-гуманітарну орієнтацію (на відміну від технократичної), вміти узагальнювати і передавати свій досвід іншим колегам і, зокрема, студентам, але при цьому не бути здатним до рефлексії, володіти сучасними педагогічними технологіями, але при цьому не бути майстром, а залишатися хорошим чи посереднім «ремісником». Щоб бути майстром, необхідно мати особистісну професійну неповторність й унікальність, свій стиль діяльності, володіти концептуальністю професійного мислення. Педагогічна майстерність $є$ індивідуальним внеском у педагогічну культуру суспільства, і лише повне усвідомлення механізмів власної діяльності уможливлює передачу майстерності іншим.

Як зазначає М. М. Фіцула, з метою підвищення професійної майстерності викладачів у вищих навчальних закладах використовують різноманітні форми методичної роботи, які також можуть бути використані і викладачами соціальної роботи для підвищення їх професійної майстерності в процесі підготовки майбутніх соціальних працівників : а) науково-практичні конференції викладачів і студентів; б) загальні конференції педагогічних працівників вищої школи, де обговорюється стан навчально-виховного процесу у вищому навчальному закладі, на факультетах, а також перспективи розвитку фахових спеціальностей; в) засідання вченої ради закладу, на яких детально аналізують рівень професійної підготовки студентів, стан навчально-виховної роботи на факультетах, обговорюють та затверджують перспективний план роботи вищого навчального 
закладу за окремими проблемами (наприклад, науково-дослідна робота студентів, методична робота з викладачами та ін.), а також розглядають досвід роботи кафедр, фракультетів щодо впровадження нових технологій навчання студентів; г) методичні семінари; д) засідання кафедр, на яких обговорюють результати роботи викладачів щодо вдосконалення навчально-виховної роботи зі студентами; е) інструктивно-методичні наради, які проводяться деканами фракультетів; є) індивідуальна самоосвітня робота викладача вищої школи; ж) індивідуальні та групові консультації із завідувачами кафедр та викладачами з реалізації управлінських функцій або для надання конкретної методичної допомоги кафедрам з питань планування роботи, визначення змісту, форм наукової, організаційно-методичної роботи; з) робота над створенням свого особистісного іміджу [10].

Ефективною формою підвищення педагогічної майстерності викладачів соціальної роботи є підвищення кваліфрікації в інших навчальних закладах та стажування, зокрема у закордонних ВН3, що збагачують індивідуальний досвід людини, надають можливість ознайомитися і практикувати різні моделі створення і поширення знань, дозволяють розширити мережу контактів і спілкування, поглибити знання іноземної мови.

Висновки. Отже, на основі вище викладеного, слід зазначити, що у контексті соціальнополітичних перетворень в українському суспільстві посилюється роль демократичних та гуманістичних цінностей, спрямованих на зміцнення віри в людину та її можливості. Майстерність викладача соціальної роботи є важливим чинником підвищення ефективності цього процесу, надання йому емоційно-чуттєвого забарвлення, актуалізації у свідомості студентської молоді ідей та цінностей гуманістичного змісту та спрямованості.

Сучасна вища школа, орієнтуючись на вимоги ринкової перебудови всіх сфер соціального життя держави, потребує нового викладача - компетентного і всебічно освіченого фахівця, високого професійного і культурного рівня, готового завжди оволодівати новими технологіями навчання і виховання. За цих умов вища школа повинна виступити координатором у створенні сприятливих умов й узагальненні системи впливів всіх соціально-виховних інститутів 3 метою оптимізації особистісного розвитку майбутнього фахівця соціальної сфери.

Саме тому, сучасне суспільство шукає особистостей, що вміють мислити оригінально, котрі проявляють інтерес до створення тих умов, які сприяють виявленню творчих здібностей, фрормуванню індивідуального стилю діяльності. Ця проблема особливо важлива для тих ВН3, які готують висококваліфікованих фахівців із соціальної роботи, котрі забезпечують прогрес у різних сорерах людської діяльності, будуть відповідати вимогам оновленого суспільства, стануть активними учасниками соціально-культурного процесу.

\section{Література}

1.Абдуллина, О. А. Общепедагогическая подготовка учителя в системе высшего педагогического образования: учебное пособие / О. А. Абдуллина. - М.: Просвещение, 2009. - 141 с.

2. Азаров, Ю.П. Тайны педагогического мастерства / Ю. П. Азаров - М. : Издательство Московского психологосоциального института; Воронеж: Издательство НПО «МОДЭК», 2004. - 432 с.

3. Гринькова, В. М. Формування педагогічної культури майбутнього вчителя (теоретичний та методичний аспекти). автореф. дис. док. пед. наук / В. М. Гринькова - К., 2001. - 45 с.

4.Зязюн, І. А. Педагогіка добра: ідеали і реалії. - К. : МАУП. 2000. - 312 с.

5. Кремень, В. Г. Філософрія освіти XXI століття / В. Г. Кремень // Педагогіка і психологія. - 2003. - № 1 (XXXVIII). - C. 6-16.

6. Кузьмина, Н. В. Психологическая структура деятельности учителя / Н. В. Кузьмина, Н. В. Кухарев. - Гомель : ГГУ, 1976. -57 с.

7. Мороз, О. Г. Педагогіка і психологія вищої школи: Навчальний посібник для молодих викладачів, аспірантів і майбутніх магістрів / О. Г. Мороз, О. С. Падалка, В. І. Юрченко. - К. : НПУ ім. М. П. Драгоманова, 2003. - 267 с.

8. Педагогічна майстерність: підручник / І. А. Зязюн, Л. В. Крамущенко, І. Ф. Кривонос та ін.; за ред. І. А. Зязюна. - К. : Вища шк., 1997. - 349 с.

9. Скачкова, Г. С. Особливості сучасної професійної підготовки соціальних працівників у вищих навчальних закладах. / Г.С. Скачкова // Вісник НТУУ «КПІ». Філософрія. Психологія. Педагогіка. - 2016. - Випуск 3 (48). - С. 128-132.

10. Фіцула, М. М. Педагогіка вищої школи: навч. посіб. [Електронний ресурс] / М. М. Фіцула. - К. : Академвидав, 2010. - 454 с. - Режим доступу: http://pidruchniki.com/70124/pedagogika/pedagogichna_maysternist_vikladacha_ vischogo_navchalnogo_zakladu.

(2009) Obshchepedagogicheskaya podgotovka uchitelya $v$ sisteme vysshego pedagogicheskogo obrazovaniya [General pedagogical teacher training in higher pedagogical education]. Moscow: Prosveshchenie [in Russian]. 
2. Azarov, Yu. P. (2004). Tayny pedagogicheskogo masterstva [Secrets of pedagogical skill]. Moscow: Izdatelstvo Moskovskogo psihologo-socialnogo instituta. Voronezh: Izdatelstvo NPO «MODEHK» [in Russian].

3. Hrynkova, V. M. (2001). Formuvannia pedahohichnoi kultury maibutnoho vchytelia (teoretychnyi ta metodychnyi aspekty) [Formation of pedagogical culture of future teacher (theoretical and methodological aspects)]. Extended abstract of Doctor's thesis. Kyiv [in Ukrainian].

4. Ziaziun, I. A. (2000). Pedahohika dobra: idealy i realii [Pedagogy of good: ideals and realities]. Kyiv: MAUP [in Ukrainian].

5. Kremen, V. H. (2003). Filosofiia osvity XXI stolittia [Philosophy of education of 21th century]. Pedahohika i psykholohiia, 1 (XXXVIII), 6-16 [in Ukrainian].

6. Kuzmina, N. V. (1976). Psihologicheskaya struktura deyatelnosti uchitelya [Psychological structure of teacher's activity]. Gomel: GGU [in Belarusian].

7. Moroz, O. H. (2003). Pedahohika i psykholohiia vyshchoi shkoly [Pedagogy and psychology of higher school]. Kyiv: NPU im. M. P. Drahomanova [in Ukrainian].

8. Ziaziun, I. A., Kramushchenko, L. V., Kryvonos, I. F., et. al. (1997). Pedahohichna maisternist [Pedagogical skills]. Kyiv: Vyshcha shk [in Ukrainian].

9. Skachkova, H. S. (2016). Osoblyvosti suchasnoi profesiinoi pidhotovky sotsialnykh pratsivnykiv u vyshchykh navchalnykh zakladakh [The features of modern professional training of social workers in higher educational institutions]. Visnyk NTUU Filosofiia. Psykholohiia. Pedahohika - Bulletin of the NTUU "KPI". Philosophy. Psychology. Pedagogy, 3(48), 128-132 [in Ukrainian].

10. Fitsula, M. M. (2010). Pedahohika vyshchoi shkoly [Pedagogy of higher education]. Retrieved from http://pidruchniki.com/70124/pedagogika/pedagogichna_maysternist_vikladacha_vischogo_navchalnogo_zakladu [in Ukrainian].

Надійшла 03.12.2018

Бібліографічний опис для цитування:

Острянко, Т. С. Педагогічна майстерність викладача соціальної роботи - запорука успішного професійного становлення майбутніх соціальних працівників / Т. С. Острянко, Л. Ф. Лєскова // Проблеми соціальної роботи: філософрія, психологія, соціологія. - 2018. - № 2 (12). - С. 74-80. 